\title{
Non-occlusive distal duodenal and proximal jejunal necrosis - a case report
}

\section{Nienaczyniowa martwica dolnej części dwunastnicy i początkowego odcinka jelita czczego - opis przypadku}

\author{
Andrzej Żyluk ${ }^{1 凶}$, Wojciech Jagielski ${ }^{1}$, Bernard Piotuch $^{2}$ \\ 1 Pomorski Uniwersytet Medyczny w Szczecinie, Klinika Chirurgii Ogólnej i Chirurgii Ręki, ul. Unii Lubelskiej 1, 71-252 Szczecin \\ Pomeranian Medical University in Szczecin, Department of General and Hand Surgery \\ ${ }^{2}$ Samodzielny Publiczny Zakład Opieki Zdrowotnej Ministerstwa Spraw Wewnętrznych w Szczecinie, Oddział Chirurgii z Pododdziałem Chirurgii Naczyniowej \\ i Urazowo-Ortopedycznej, ul. Jagiellońska 24, 70-382 Szczecin \\ Independent Public Health Care Center of the Ministry of the Interior in Szczecin, Department of Surgery with the Subunit of Vascular \\ and Traumatic-Orthopedic Surgery \\ $\bowtie$ azyluk@hotmail.com
}

\begin{abstract}
The article presents a case of isolated, non-occlusive necrosis of the distal duodenum and proximal jejunum in an elderly patient, burdened with chronic obstructive lung disease, but without concomitant vascular or gastrointestinal disease. Diagnostic investigations included endoscopy and angio-CT. Surgery was peformed and treatment comprised resection of the necrotic parts of the duodenum and jejunum, followed by gastro-jejuno anastomosis and pyloroplasty. Post-operative course was complicated by upper
\end{abstract}

gastrointestinal (GI) bleeding from multiple gastric ulcers, developed due to duodenal juice reflux into the stomach. The bleeding was successfully controlled by intensive conservative treatment with a proton pump inhibitor and somatostatin. Unfortunately, further complications developed, including urinary tract infection, respiratory failure, and sepsis, which eventually caused patient death in the intensive care unit, 2 months after the operation. Keywords: non-occlusive duodenal/intestinal necrosis; upper gastrointestinal bleeding.

\begin{abstract}
ABSTRAKT
W pracy przedstawiono przypadek izolowanej martwicy dwunastnicy i początkowej części jelita czczego o etiologii nienaczyniowej u pacjentki w podeszłym wieku, która była obciążona przewlekłą obturacyjną chorobą płuc, ale nie cierpiała na żadne dolegliwości ze strony układu naczyniowego ani na choroby przewodu pokarmowego. W diagnostyce zastosowano badanie endoskopowe i angio-TK. Leczenie operacyjne polegało na wycięciu zmienionej części dwunastnicy i jelita, pyloroplastyce oraz zespoleniu jelita czczego z żołądkiem. W przebiegu pooperacyjnym wystąpiły powikłania w postaci krwawienia
\end{abstract}

z licznych wrzodów żołądka, które powstały wskutek refluksu treści dwunastniczej do żołądka. Krwawienie udało się opanować intensywnym leczeniem inhibitorem pompy protonowej i somatostatyną, ale powstały następne powikłania, takie jak zakażenia dróg moczowych, posocznica i niewydolność oddechowa, które przyczyniły się do śmierci chorej na oddziale intensywnej terapii po 2 miesiącach od operacji.

Słowa kluczowe: martwica dwunastnicy/jelita cienkiego o etiologii nienaczyniowej; krwawienie z górnego odcinka przewodu pokarmowego.

\section{INTRODUCTION}

Isolated necrosis of the duodenum is a very rare condition, which has been described mostly as a complication of acute necrotizing pancreatitis, eventration, or jejunal instussusception in children $[1,2,3,4]$. The article presents a case of isolated, non-occlusive necrosis of the distal duodenum and proximal part of the jejunum in an elderly patient, burdened with chronic obstructive lung disease, but without concomitant vascular or gastrointestinal disease.

\section{CASE REPORT}

An 81-year-old woman was admitted to the Department of Gastroenterology due to a 2-week history of abdominal pain, diarrhoea, vomiting, and anorexia, resulting in serious weakness. The patient was burdened with chronic obstructive lung disease (treated with steroids during acute periods), hypertension, and ischaemic heart disease. Abdominal pain was constant, of moderate severity, located in the upper/middle abdomen, and was not related to meal or fluid intake. During her stay at the ward, the patient underwent biochemical, radiological, and endoscopic investigations. Gastro-duodenoscopy revealed numerous ulcerations with black coating, involving the middle part of the duodenum (distal to the bulb), which suggested necrosis of the duodenum (Fig. 1). Angio-CT scanning revealed thickening (to $8 \mathrm{~mm}$ ) of the wall of the horizontal (distal) part of the duodenum, reaching to the beginning of the jejunum. Additionally, an inflammatory infiltration of fat tissue was seen surrounding these parts of the duodenum and jejunum (Fig. 2). The celiac trunk branches, upper mesenteric 
artery, and portal vein were patent, excluding ischaemic aetiology of the disease. Biochemical tests showed significantly elevated inflammatory parameters: leukocyte count $22 \mathrm{G} / \mathrm{L}$ and CRP $246 \mathrm{mg} / \mathrm{dL}$. Serum amylase and hepatic enzymes were normal. After 4 days of conservative treatment (antibiotics, fluid replacement), the general status of the patient was slightly improved with cessation of diarrhoea and vomiting. Due to uncertain diagnosis and distressing findings in gastroduodenoscopy, the patient was referred to surgical consultation. Physical examination revealed the following findings: obesity,

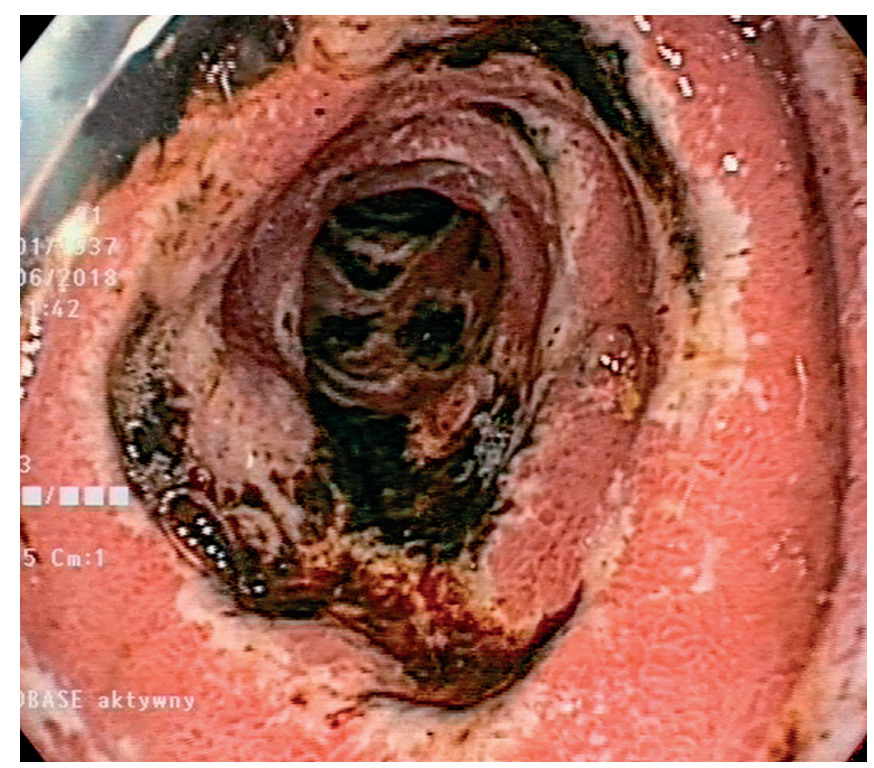

FIGURE 1. Ulcerations with black coating in the central (distal to the bulb) part of the duodenum (endoscopic findings)

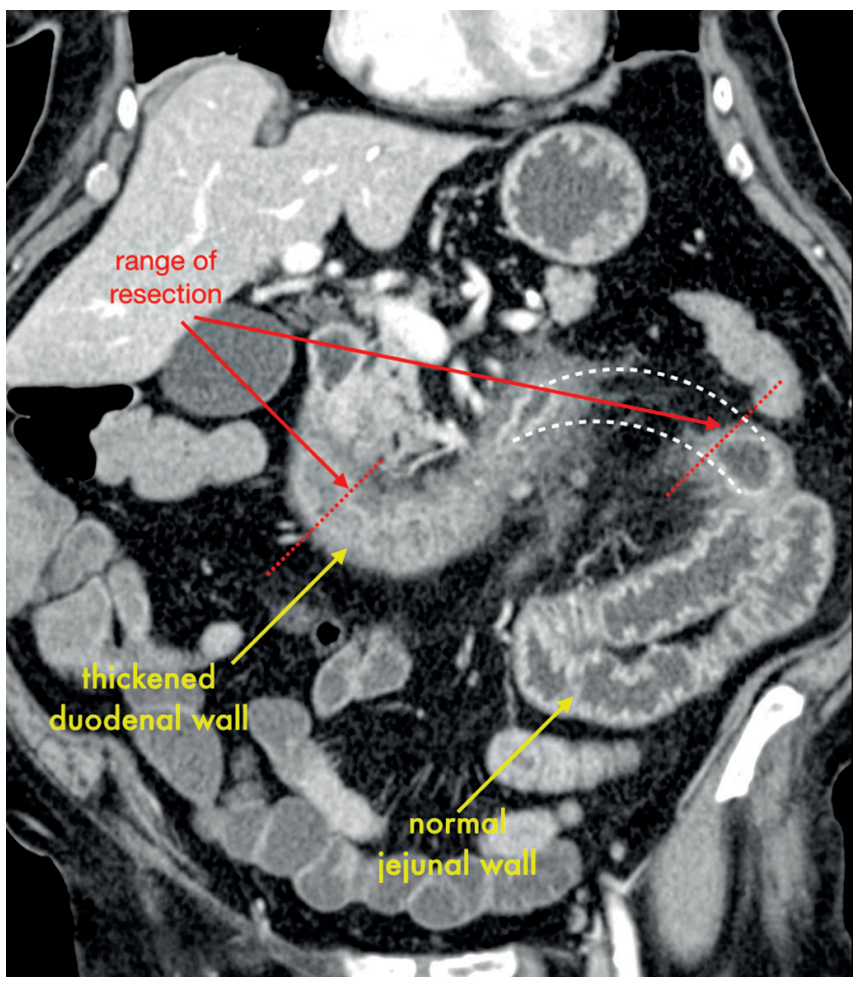

FIGURE 2. Angio-CT findings in the duodenum and proximal jejunum abdomen soft and tender at palpation in the upper/middle part without peritoneal signs. Peristalsis was lazy during auscultation and rectal examination was inconclusive. On the day of consultation, biochemical tests showed rapid elevation of inflammatory parameters including leukocyte count (from 23 to $32 \mathrm{G} / \mathrm{L}$ ) and CRP (from 246 to 348 ) over 12 hours. Although the general condition of the patient was stable, the decision to undertake surgical intervention was made due to suspicion of necrosis and duodenal and/or jejunal perforation.

\section{INTRAOPERATIVE FINDINGS}

The operation was performed in the evening hours on the day of consultation. The abdomen was opened via upper middle incision. Exposure of the Treitz ligament area showed necrosis of the distal part of the duodenum and proximal part of the jejunum and presence of turbid fluid in this area of the peritoneal cavity. No perforations of the necrotic portions of the bowel were observed. The necrosis involved almost the whole circumference of the involved bowel, except for a narrow portion close to the mesenteric margin. The remaining parts of the small and large bowel were normal. Figures 2 and 3 illustrate the range of pathological changes observed. Based on the aforementioned intraoperative findings, the decision was made to resect the necrotic parts of the duodenum and jejunum (Fig. 4). After excision, the proximal duodenal stump showed poor vascularization and further inspection revealed the presence of ulcerations, similar to those found in endoscopy (Fig. 1). Therefore, the decision was made not to anastomose the jejunum with the compromised duodenal stump, but

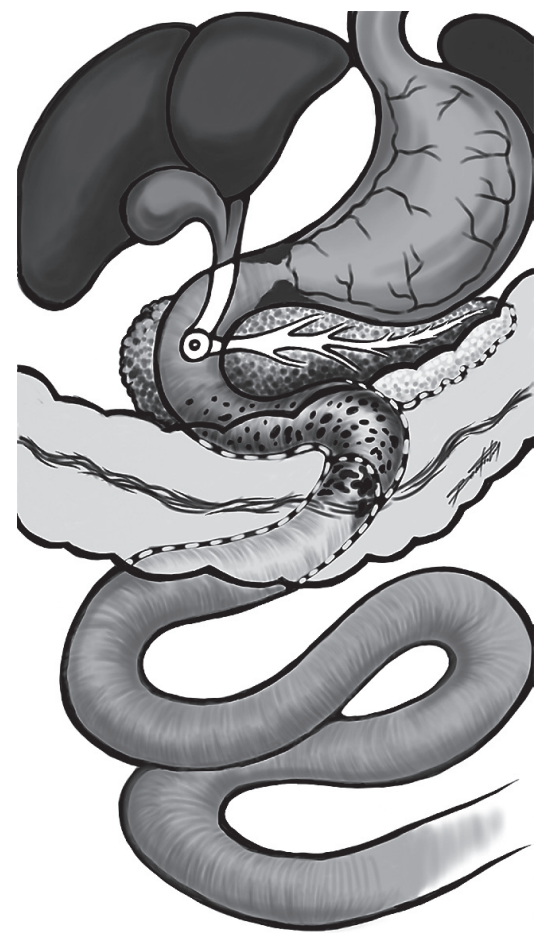

FIGURE 3. Illustration of the extent of necrosis of the duodenum and proximal jejunum (marked with thick spots) 


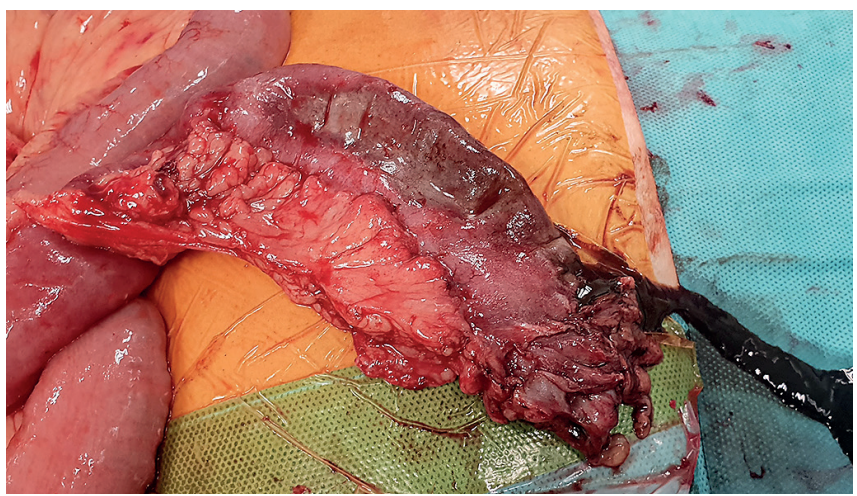

FIGURE 4. Resected portions of the duodenum and proximal jejunum

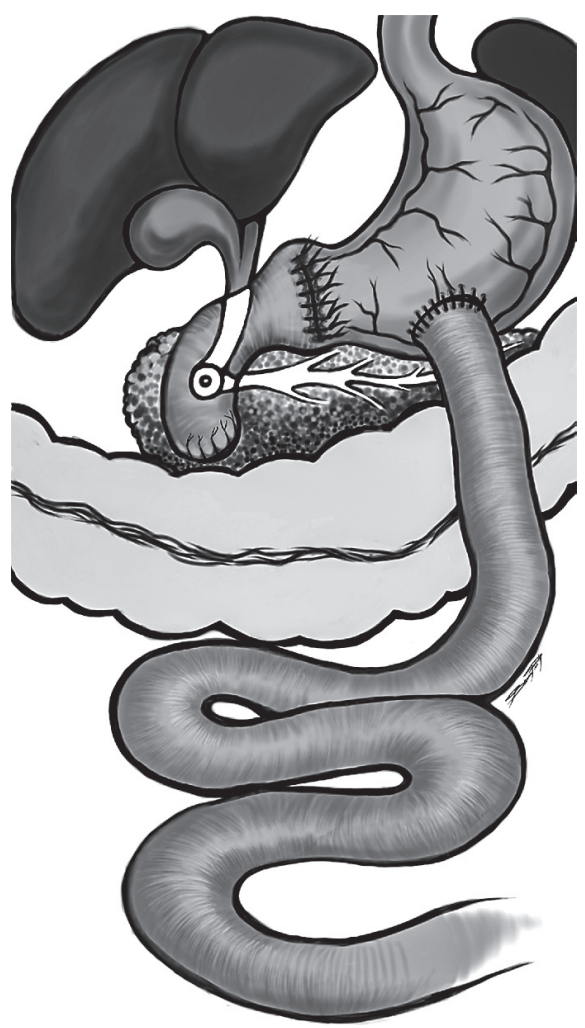

FIGURE 5. Schematic diagram of the operation performed

rather to close with one layer of interrupted stiches tightened by omental fatty flap. Continuity of the digestive tract was restored by end-to side anastomosis of the proximal jejunum with the distal part of the stomach (Fig. 5). A Heineke-Mikulicz pyloroplasty was additionally performed, with the intention of decompressing the unstable duodenal stump by draining the bile and duodenal juice into the stomach. A drain was placed in the abdominal cavity.

\section{POSTOPERATIVE COURSE}

A nasogastric tube was kept in the stomach for 4 days, until peristalsis recovered and fluid retention significantly decreased. Fluid intake was started at day 3 and oral feeding at day 5 post-op. The drain was removed at day 4 , as it showed no leakage. Postoperative course was uneventful until day 7 , when symptoms of gastrointestinal (GI) bleeding occurred in the form of bloody stools, weakness, and anaemia. Clinical picture initially suggested lower GI bleeding, which was possible as the patient had previously diagnosed diverticula in the sigmoid colon. However gastroscopy performed the next day revealed signs of haemorrhagic, ulcerative gastritis with numerous, shallow ulcerations present throughout the stomach, confirming the diagnosis of upper GI bleeding. The patient was moved into the gastroenterology ward and treatment was implemented, consisting of proton-pump inhibitor (pantoprazol, $80 \mathrm{mg} /$ day) infusion, somatostatin, and fresh-frozen plasma. Due to serious anaemia, 6 units of red cell concentrate was transfused and antibiotic therapy was continued. Three days thereafter general condition of the patient improved and signs of GI bleeding ceased. This treatment was continued throughout the next 10 days, allowing return to oral nutrition and considerations of releasing the patient home. Unfortunately, on the $20^{\text {th }}$ post-operative day ( $10^{\text {th }}$ day after GI bleeding cessation), the patient's condition rapidly deteriorated, exhibiting symptoms of urinary tract infection and sepsis, followed by respiratory failure, requiring her relocation to the Intensive Care Unit (ICU). The patient was intubated and intensive, empiric broad-spectrum antibiotic therapy was implemented, allowing control of infection and sepsis. Respiratory function did not improve sufficiently to allow her independent breathing and disconnection from a respirator. This eventually led to severe pneumonia and death of the patient one month after admission to the ICU. During the patient's stay in the ICU, no signs of GI bleeding were observed and she was fed via nasogastric tube.

Histopathological examination of the operative sample showed necrosis of the entire wall of the duodenum and proximal jejunum with perforation and excessive ulceration of the mucosa with concomitant purulent inflammatory infiltration of the gut wall, including both margins of the resection.

\section{DISCUSSION}

The presented case is interesting for several reasons. Isolated necrosis of the duodenum or jejunum is very rare and has been described only as a complication of acute, necrotizing pancreatitis or eventration in children $[1,2,3]$. A case of necrosis of the whole duodenum, complicated by retroperitoneal perforation, was reported in an adult patient suffering from intussusception of the jejunum [4]. However, none of these cases was similar to the one presented in this study. Necrosis of the distal part of the duodenum and proximal jejunum was not caused by vascular disturbances (non-occlusive), as angio-CT scanning showed patency of the main vessels supplying these parts of the intestine. The most likely cause of this pathology was inflammatory process, suggested by significantly elevated leukocyte count and CRP concentration. Localization of necrosis, confined to the distal part of the duodenum and proximal 
jejunum, is difficult to explain; it does not correspond to any anatomical area of blood supply by a specific artery. Clinical course was also vague, with a two-week period of vomiting and diarrhoea, followed by exacerbation of inflammation and bowel necrosis. In our earlier report, we presented a case of spontaneous necrosis of the colon, with no evidence of arterial occlusion by embolism or thrombus. This rare condition is called "non-occlusive ischaemic colitis" [5].

All causes of this pathology reported to date concern only the large intestine, but not the small (including the duodenum) which also makes the presented case unique.

The resolution of the intraoperative situation was also nonstandard, although related to the patient's age and overall condition. The need to perform resection of the necrotic parts of the bowel was obvious, but the method of restoration of the digestive tract was controversial. The simplest and best method would be to anastomose the duodenal stump with the proximal jejunum. However, poor vascularization of the stump, observed immediately after resection, suggested a high risk of anastomotic failure. The results of duodenoscopy and angioCT also confirmed this suspicion - Figures 1 and 2. Therefore, simple closure of the duodenal stump followed by its tightening with omental fat seemed to be a safer option (although also risky). Restoration of the continuity of the digestive tract was achieved by gastro-jejuno anastomosis and pyloroplastyfacilitated outflow of duodenal fluid into the stomach, decompressing the uncertain duodenal stump. This solution appeared effective, as no leakage from the stump was observed. However, this non-anatomical anastomosis resulted in constant reflux of duodenal juice and bile into the stomach which caused irritation of the mucosa, ulcerations, and haemorrhagic gastritis. This complication was effectively treated with proton-pump inhibitors and somatostatin. It is difficult to state whether development of urinary/respiratory tract infection and sepsis was directly related to the upper GI bleeding, but undoubtedly all the complications in the course of the patient's dramatic history contributed to compromising her general immunity and increasing her susceptibility to infection.

The question warrants asking: in the case of her survival, could the patient function with constant duodenal reflux? It seems that she could function almost normally, but only with constant intake of proton-pump inhibitors and - optionally other drugs, i.e. somatostatin. A similar method for restoring continuity of the digestive tract to that reported in this case was employed after partial gastrectomy with the Reichel-Polya method, a technique used until the 1980s, which also caused constant duodenal reflux into the stomach. Probably the optimal solution in this case would be performing Whipple's resection of the head of the pancreas with duodenectomy, but considering the patient's age, condition, concomitant diseases, and the emergency nature of operation, it would be burdened by a high risk of failure.

The authors found only few case reports of isolated duodenal necrosis in the literature.

Sakorafas et al. reported 3 such cases, occurring in the course of acute necrotizing pancreatitis managed by "open abdomen" method. In all patients, duodenal necrosis caused development of fistulas which were treated by combined internal (from the lumen of the duodenum) and external drainage. In one case, pyloric closure and biliary tract drainage by Kehr's T-tube was additionally performed to reduce gastric fluid and bile flow to the duodenum. All 3 patients survived following almost one-year stay in the ICU [1].

Colović et al. report two similar cases of duodenal necrosis complicating acute necrotizing pancreatitis in young adults. In both cases, the only possible method for reconstructing the digestive tract following resection of necrosis was Whipple's pancreato-duodenectomy. One of these patients survived [2].

Jabłoński et al. described a case of distal duodenum and proximal jejunum necrosis in an adolescent, in the course of jejunal intussusception, nearby the Treitz ligament. This patient had previously suffered from nonspecific abdominal pain lasting several months and the direct cause of hospitalization was exacerbation of pain, vomiting, and apparent peritoneal signs upon examination. Biochemical parameters of inflammation were only slightly elevated and intussusception of the bowel was diagnosed by ultrasound and CT scanning. Intraoperatively, an enormously distended and necrotic distal part of the duodenum and proximal part of the jejunum were found. As in one of the previously mentioned cases, the only possible operative option was Whipple's pancreato-duodenectomy, which was successfully performed and the patient eventually recovered $[3,4]$.

Only one case report similar to that presented in this study was found, in Japanese medical journal (English abstract). The authors presented the case of an 82-year-old woman with "acute abdomen" symptoms requiring emergency laparotomy. Intraoperatively, necrosis of the distal part of the duodenum and proximal part of the jejunum was found and resected, without attending to the duodenal stump, which was left open. Three days thereafter, laparotomy was repeated, an additional fragment of the jejunum was resected due to necrosis, and the duodenal stump was anastomosed with the jejunum. Postoperative course was complicated, but the patient eventually survived [5, 6].

The presented case appears interesting in view of the extremely rare pathology that is isolated, non-occlusive, inflammatory necrosis of the duodenum and jejunum. The operative solution applied to this difficult problem was also non-standard, although the occurrence of complications and death of the patient hindered assessment of its actual effectiveness.

\section{REFERENCES}

1. Sakorafas GH, Tsiotos GG, Sarr MG. Experience with duodenal necrosis. A rare complication of acute necrotizing pancreatitis. Int J Pancreatol 1999;25:147-9.

2. Colović R, Grubor N, Radak V, Colović N, Jovanović M, Stojković M. Necrosis of the duodenum resulting from acute necrotising pancreatitis and treated with complete duodenopancreatectomy. Srp Arh Celok Lek 2005;133(11-12):510-3. 
3. Fouad D, Lee GJ, Upadhyaya M, Drake D. Inflammatory duodenal necrosis complicating gastroschisis. J Indian Assoc Pediatr Surg 2016;21:190-2.

4. Jabłoński S, Kustalik S, Klejszmit P, Misiak P. Total duodenal necrosis with retroperitoneal perforation in an adolescent with jejunal intussusceptions. J Dig Dis 2016;17:483-5.
5. Hunter JP, Saratzis A, Zayyan K. Spontaneous, isolated caecal necrosis: report of a case, review of the literature and updated classification. Acta Chir Belg 2013;113:60-3.

6. Ito $\mathrm{Y}$, Igarashi $\mathrm{Y}$, Inaba $\mathrm{M}$, Ohigashi $\mathrm{H}$. Non-occlusive mesenteric ischemia with duodenal necrosis. Jap J Gastrointest Surg 2015;48:565-71. 